\title{
Psocoptera of Canada
}

\author{
Johannes E. Anonby' \\ I Fylkesmannen i Sogn og Fjordane, Njøsavegen 2, NO-6863 Leikanger, Norway \\ Corresponding author: Johannes E. Anonby (fmsfja@fylkesmannen.no)
}

Academic editor: D. Langor | Received 19 June 2018 | Accepted 13 July 2018 | Published 24 January 2019

http://zoobank.org/66CC5ADB-A9F4-4AE6-860A-EC1CBF2F8120

Citation: Anonby JE (2019) Psocoptera of Canada. In: Langor DW, Sheffield CS (Eds) The Biota of Canada A Biodiversity Assessment. Part 1: The Terrestrial Arthropods. ZooKeys 819: 295-299. https://doi.org/10.3897/ zookeys.819.27640

\begin{abstract}
At present, 108 species of Psocoptera are known from Canada, an increase of 50\% from the known fauna reported in 1979. Of these, 56 have been barcoded, representing 162 Barcode Identification Numbers (BINs). An additional 67 species are expected to occur in Canada but remain undiscovered or undescribed, meaning that only $62 \%$ of the fauna is currently documented.
\end{abstract}

\section{Keywords}

bark lice, biodiversity assessment, Biota of Canada, book lice, Psocoptera

Psocoptera, commonly known as bark lice and book lice, comprised about 4400 species known worldwide by the time the World catalogue was published, with 294 species in North America (Lienhard and Smithers 2002). By the end of 2015, the worldwide species number had increased to 5958 (C Lienhard pers. comm.). Mockford (2012) lists 397 species from North America south to the Tropic of Cancer.

Psocoptera are generally herbivores or detritivores, feeding on microflora and organic debris. Species associated with human dwellings, most belonging to the suborders Trogiomorpha and Troctomorpha, often feed on molds as well as dead insects. The outdoor-living species, mostly of the suborder Psocomorpha, may be classified as either bark-dwellers or leaf-dwellers, with associated differences in feeding habits 
(e.g., Mockford 1993, Lienhard 1998). Many domiciliary species are found outdoors if conditions are favourable. Since indoor species are readily spread by human commerce around the world, it may often be difficult to say where they originally came from, and whether they are native or introduced species or populations.

Although classified as an order for much of recent history, Yoshizawa and Lienhard (2010) showed that Phthiraptera, the true lice, have evolved within the Troctomorpha suborder of Psocoptera. Phthiraptera and the family Liposcelididae of Psocoptera are probably sister groups, or various lines of Phthiraptera may have budded off independently in the infraorder Nanopsocetae within Troctomorpha. To maintain monophyly, the former orders of Psocoptera and Phthiraptera are now placed in the order Psocodea. For practical reasons, however, since true lice and psocids have quite different ecology, and are studied by different methods and by different experts, Psocoptera is still typically treated as a group in the traditional way, but referred to as Psocodea: 'Psocoptera'. This practical approach is also adopted in the present work.

Since the last review of Canadian Psocoptera (Mockford 1979), there has been relatively little effort focused on this group in Canada, and Canada has never had an expert working on this group. However, fortunately there have been some advances in understanding the composition, distribution, identification, and biogeographical affinities of the Canadian fauna through the work of Edward L. Mockford (USA). His handbook for identification of North American Psocoptera is mainly based on studies in the USA (Mockford 1993). However, since species numbers of Psocoptera generally decrease rapidly with latitude, and there seems to be few species that are restricted to the boreal or northwards, the handbook covers Canadian species very well. The handbook divided the North American Psocoptera species into distinct distribution patterns, whose corresponding geographic areas extended into Canada to various degrees, as well as listed introduced species. The biogeographic analysis was further developed in Mockford (2012) who discussed modes of dispersal, which is relevant to understanding the Canadian fauna as part of the North American and worldwide fauna. The website http://Psocodea.SpeciesFile.org provides much information on Psocodea: 'Psocoptera', although it is not very specific for the Canadian fauna.

Mockford (1979) reported 72 known species from Canada and estimated that an additional 31 species remained to be discovered or described from the country, thus predicting a total fauna of about 103 species. Lienhard (2016) found that the world catalogue by Lienhard and Smithers (2002) contained references to 83 species reported from Canada. However, the report of Blastopsocus semistriatus (Walsh) in Mockford (2002) had gone unnoticed since it was published too late to be included in the catalogue. The number of Canadian Psocoptera species known by 2016 was therefore 84 .

I collected more than 4000 specimens of Psocoptera during two months in Canada in 1993, mainly from British Columbia and Ontario with a few samples from Alberta and Yukon. The material was identified by me, with more difficult cases confirmed or corrected by Edward Mockford. Although the records were not published, 


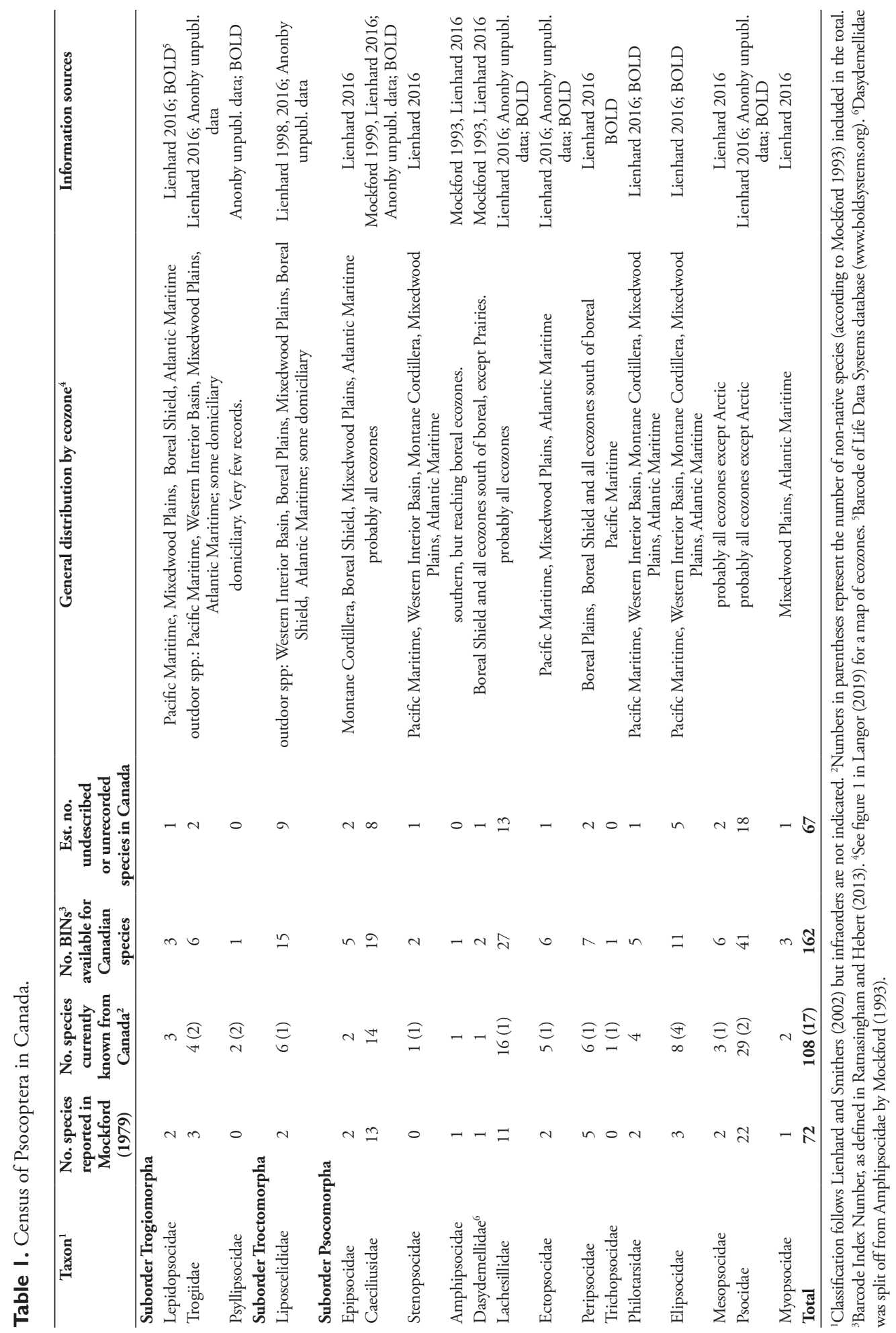


this collection added 12 additional described species to the national checklist, not counting an Anomopsocus sp. from the Montane Cordillera of British Columbia that may represent a new species.

The Barcode of Life Data System database (BOLD) (Ratnasingham and Hebert 2007) contains more than 14,000 DNA barcodes for specimens of Psocoptera from Canada. Among the 162 BINs represented by Canadian specimens, there are another 12 named species that represent new Canadian records of described species. Thus, the number of currently known species of Canadian Psocoptera is 108, an increase of 50\% since 1979 (Table 1).

Although a large number of Canadian specimens have been barcoded, there are still 52 recorded species that have not yet been sampled genetically. Furthermore, some of the barcoded Canadian material has not yet been identified to species, and in some cases identification is incorrect, so it is possible that once these identifications are confirmed or corrected, additional known Canadian species will have associated BINs. The estimates of yet-undocumented species in Canada were calculated based on available number of BINs not yet assigned to Canadian species and consideration of the number of species (21) present in adjacent states of the USA but still not found in Canada but likely to be there. Undocumented species will likely include unidentified described species and undescribed taxa (including cryptic species). Using an approach that recognizes the likelihood that not every BIN represents a unique species, that species may share BINs, and that not every species in Canada has been barcoded, it is conservatively estimated that another 67 species occur in Canada, representing 38\% of the total anticipated fauna (Table 1).

In general, the Psocoptera fauna of Canada is not well sampled so that even modest inventory effort could result in new jurisdictional records. New species remain to be discovered and described in all ecozones. New taxa may sometimes be found in places where they are not expected, and where there are not many insects at all, such as in caves and other underground habitats. The Arctic ecozone should not be forgotten, even though the number of species may be very low. Odd-looking, winged Psocoptera have been found on barren rocks in mountains north of the tree line in Norway (J Anonby unpubl. data), so it is likely that sampling various habitats in the vast northern parts of Canada will reveal new species which are rare or absent farther south. Continued barcoding efforts will help identify cryptic species, elucidate intraspecific genetic diversity, and help detect rare and relict species that may require conservation measures as well as non-native species that may be threatening natural ecosystems. The distinction between native and introduced species may be particularly demanding in Psocoptera, given regular long-distance dispersal in many species.

\section{Acknowledgements}

Thanks to Jeremy deWaard for providing BIN data for Canadian Psocoptera, with links to their respective BOLD pages. 


\section{References}

Langor DW (2019) The diversity of terrestrial arthropods in Canada. In: Langor DW, Sheffield CS (Eds) The Biota of Canada - A Biodiversity Assessment. Part 1: The Terrestrial Arthropods. ZooKeys 819: 9-40. https://doi.org/10.3897/zookeys.819.31947

Lienhard C (1998) Psocoptères euro-méditerranéens. Faune de France Vol. 83, xx + 517 pp. Lienhard C (2016) Country checklists of the Psocoptera species of the World, extracted from Lienhard \& Smithers, 2002: "Psocoptera (Insecta) - World Catalogue and Bibliography". Psocid News, Special Issue 1: 1-123. http://www.psocodea.org/psocid_news/PN_S1.pdf

Lienhard C, Smithers CN (2002) Psocoptera (Insecta): World Catalogue and Bibliography. Muséum d'histoire naturelle, Genève, Instrumenta Biodiversitatis Vol. 5, xli + 745 pp.

Mockford EL (1979) Psocoptera. In: Danks HV (Ed.) Canada and its insect fauna. Memoirs of the Entomological Society of Canada No. 108, 324-326. https://doi.org/10.4039/ entm111108324-1

Mockford EL (1993) North American Psocoptera (Insecta). Sandhill Crane Press, Gainesville, Florida, Flora and Fauna Handbook 10, xviii + 455 pp.

Mockford EL (1999) A classification of the Psocopteran Family Caeciliusidae (Caeciliidae Auct.). Transactions of the American Entomological Society 125(4): 325-417.

Mockford EL (2002) The Blastopsocus semistriatus species complex in the United States and Canada (Psocoptera: Psocidae). Journal of the New York Entomological Society 110(3-4): 351-364. https://doi.org/10.1664/0028-7199(2002)110[351:TBSSCI]2.0.CO;2

Mockford EL (2012) Aspects of the biogeography of North American Psocoptera (Insecta). In: Stevens L (Ed.) Global Advances in Biogeography, 307-328.

Ratnasingham S, Hebert PDN (2007) BOLD: The Barcode of Life Data System (http://www. barcodinglife.org). Molecular Ecology Notes 7(3): 355-364. https://doi.org/10.1111/ j.1471-8286.2007.01678.x. PMID:18784790

Ratnasingham S, Hebert PDN (2013) A DNA-based registry for all animal species: the Barcode Index Number (BIN) system. PLoS ONE 8(7): e66213. https://doi.org/10.1371/journal. pone.0066213

Yoshizawa K, Lienhard C (2010) In search of the sister group of the true lice: a systematic review of booklice and their relatives, with an updated checklist of Liposcelididae (Insecta: Psocodea). Arthropod Systematics and Phylogeny 68: 181-195. 